
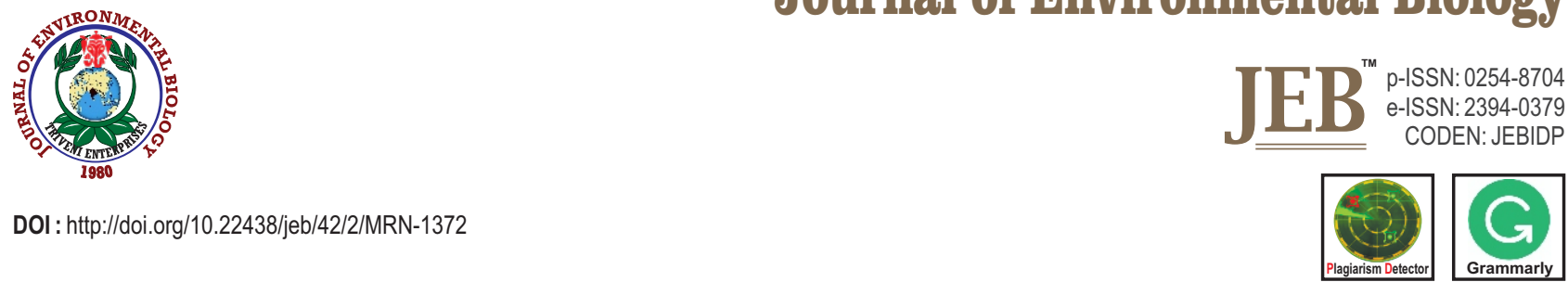

\title{
Nutrient management practices for improved crop and water productivity, grain quality and energy productivity of promising rice cultivars in Eastern Himalayas
}

\author{
M.N. Harish', A.K. Choudhary ${ }^{1 *}$, Y.V. Singh ${ }^{2}$, V. Pooniya ${ }^{1}$, A. Das ${ }^{3}$, S. Babu ${ }^{3}$, A. Dass ${ }^{1}$ and T. Varatharajan ${ }^{1}$ \\ ${ }^{1}$ Division of Agronomy, ICAR-Indian Agricultural Research Institute, New Delhi-110 012, India \\ ${ }^{2}$ Division of Microbiology, ICAR-Indian Agricultural Research Institute, New Delhi-110 012, India \\ ${ }^{3}$ ICAR-Research Complex for North-Eastern Hill Region, Barapani-793 103, India \\ *Corresponding Author Email : anilhpau2010@gmail.com
}

\section{Abstract}

Aim: To assess the influence of nutrient management practices on crop and water productivity, grain quality, energy productivity and profitability in promising rice genotypes of Eastern Himalayas.

Methodology: An experiment was conducted at 'Lowland Research Block' of ICAR-RC-NEHR, Barapani, Meghalaya to assess the influence of different nutrient management practices [Organic nutrient management (through FYM + remaining P through rock phosphate); integrated nutrient management (INM) $(50 \%$ NPK through fertilizers $+50 \% \mathrm{~N}$ through FYM + remaining $P$ through rock phosphate); inorganic nutrient management (fertilizers); and absolute control] and rice varieties [Shahsarang-1, Lumpnah and Megha semi-aromatic-2] on productivity, quality, energetic and profitability replicated thrice in a split-plot design.

Results: Rice grain yield was significantly higher in INM practice (4.18 tha $^{-1}$ ) followed by inorganic (4.02 $\left.\mathrm{t} \mathrm{ha}^{-1}\right)$ and organic practice $\left(3.74 \mathrm{t} \mathrm{ha}^{-1}\right)$. INM practice exhibited highest hulling $(68.6 \%)$, milling $(59.9 \%)$, head-rice recovery $(53.6 \%)$, protein content $(7.56 \%)$ and protein yield $\left(329 \mathrm{~kg} \mathrm{ha}^{-1}\right)$ followed by inorganic, organic practice and control, respectively. However, gross and net returns and $\mathrm{B}: \mathrm{C}$ ratio were significantly greater in inorganic practice followed by INM practice. Highest TWUE $\left(3.17 \mathrm{~kg} \mathrm{ha}^{-1} \mathrm{~mm}^{-1}\right)$, water productivity (47.6 INR ha $\mathrm{mm}^{-1}$ ), energy output (140342 $\mathrm{MJ} \mathrm{ha}^{-1}$ ) as well as net energy (130813 $\left.\mathrm{MJ} \mathrm{ha}^{-1}\right)$ were recorded in INM practice.

Interpretation: INM practice and rice variety 'Shahsarang-1' can be recommended to farmers for enhancing the rice productivity, profitability, resource-use efficiency and soil health in eastern Himalayan region of India.

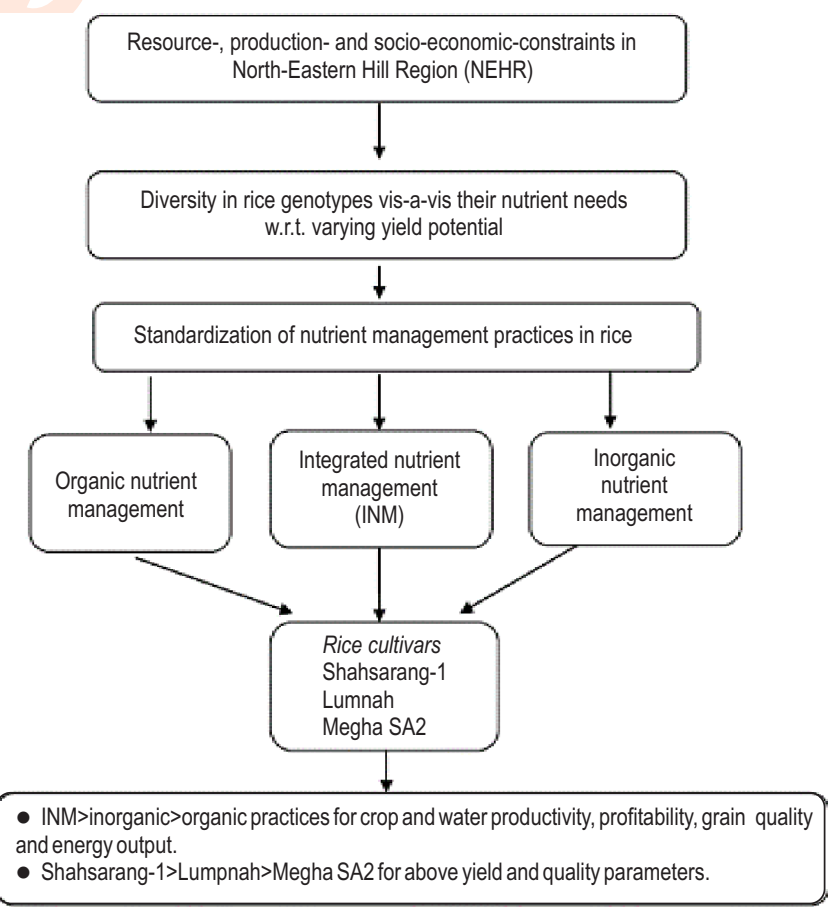

Key words: Energetics, Grain quality, Integrated nutrient management, Rice varieties, Water-use efficiency

How to cite : Harish, M.N., A.K. Choudhary, Y.V. Singh, V. Pooniya, A. Das, S. Babu, A. Dass and T. Varatharajan: Nutrient management practices for improved crop and water productivity, grain quality and energy productivity of promising rice cultivars in Eastern Himalayas. J. Environ. Biol., 42, 309-318 (2021). 


\section{Introduction}

Rice (Oryza sativa L.) is a staple food crop of south-east Asia in general and north-eastern states of India in particular with $\sim 3.51 \mathrm{~m}$ ha acreage accounting for more than $80 \%$ of total cultivated area of the region and $7.8 \%$ of total national rice area (Harish et al., 2019). However, rice production in this region is $\sim 5.5 \mathrm{mt}$ production with an average yield of $1.57 \mathrm{tha}^{-1}$ which is far below the national averages of $2.08 \mathrm{t} \mathrm{ha}^{-1}$, owing to various production constraints and resource vulnerabilities (Yadav et al., 2019). During post-green revolution period, introduction of improved varieties has eventually enhanced the rice yield in this remote region by about $40 \%$. However, there is ample scope for enhancing the rice productivity, profitability and soil health by adopting suitable agronomic practices in the region. Diverse agro-climatic conditions alongwith varying physiographic conditions have led to immense variability among rice cultivars in north-eastern region. North-east India is characterized with high soil acidity $/ \mathrm{Al}^{+3}$ toxicity, heavy soils, carbon loss, and severe water scarcity during most parts of year though it receives high rainfall (Verma et al., 2017). Organic matter addition is considered as a noble intervention to improve soil physico-chemical and microbiological properties besides enriching soil fertility (Paul et al., 2014). Thus, application of organic manures may improve the soil health for harnessing better rice yield in this region.

In NE India, continuous mono-cropping of rice has posed a serious threat to its sustainability characterized with stagnant crop productivity, declining soil organic carbon (SOC), multi-nutrient deficiencies with poor microbiological activities (Verma et al., 2017). In order to harness better crop yield, it is the genotype of any crop which plays a pivotal role in yield expression under given set of environmental and crop management situations (Choudhary and Suri 2018a; 2018b). So, development and screening of location-specific high yielding varieties (HYVs) w.r.t. to given set of input/production factors like efficient nutrient management etc., is highly important to harness the production potential of rice with better resource-use efficiency and energy output in this far eastern part of the country having diverse agroclimatic variability. With this background, the current study aimed at investigating the effect of different nutrient management practices and promising rice cultivars on productivity, profitability, quality, resource-use efficiency and energy dynamics of rice cultivation in the Eastern Himalayan region of India.

\section{Materials and Methods}

Study area, meteorological parameters: The experiment was conducted at the 'Lowland Research Block' of the Experimental Farm of ICAR-Research Complex for North Eastern Hill Region, Barapani, Meghalaya. Soil of the experimental farm was acidic in nature. Initial chemical and physical properties of soil with their determination methods are presented in Table 1. Climate of experimental site is subtropical type with high rainfall where south-west monsoons contribute a major part of rainfall during rice season. Mean annual normal rainfall ranges between
1750-2450 mm with July and August as the wettest months. Mean weekly meteorological parameters observed during current rice crop season are presented in Fig. 1. A total rainfall of 1646 $\mathrm{mm}$ was received during the rice cropping season (Fig. 1).

Experimental details and crop management: The experiment was laid-out in a split-plot design replicated thrice with four mainplot treatments [Organic (through FYM + remaining P through rock phosphate); integrated nutrient management (INM) $(50 \%$ NPK through fertilizers $+50 \% \mathrm{~N}$ through FYM + remaining $P$ through rock phosphate); inorganic nutrient management (fertilizers); and absolute control] and three sub-plot treatments [3 rice varieties viz. Shahsarang-1, Lumpnah and Megha semiaromatic-2]. Rice nursery was grown using raised-bed method following recommended practices (Verma et al., 2017). The 30days old seedlings were transplanted in the puddled field on 19th July, 2016. Seedlings were transplanted in square pattern at spacing of $20 \times 20 \mathrm{~cm}$. In organic main-plot treatments, FYM was applied before field ploughing. In inorganic main-plots treatments, the NPK was applied @ 80:60:40 kg ha-1 through urea, single super phosphate and muriate of potash. Urea was applied in 3-splits (50\% as basal $+25 \%$ at tillering $+25 \%$ at panicle initiation).

In INM main-plot treatments, 50\% NPK nutrient requirement was fulfilled through recommended dose of fertilizers (RDF) and remaining 50\% requirement was fulfilled through FYM. Urea was again applied in 3-splits ( $50 \%$ as basal + $25 \%$ each at tillering and panicle initiation). A continuous submergence of $5 \pm 2 \mathrm{~cm}$ was maintained in plots till grain-filling stage, thereafter it was drained out. Two hand-weeding (20 and 55 DAT) and one cono-weeding (35 DAT) helped in managing weeds. Recommended crop and input management practices were followed for raising the crop as suggested by Rana et al. (2014), except nutrient management treatments. At crop maturity, two rows on all the sides of the plot were removed as border and remaining hills were harvested as net plot $\left(18 \mathrm{~m}^{2}\right)$. Crop harvesting was done on $21^{\text {st }}$ Nov., 2016 manually using sickles.

Root growth analysis and yield estimation: Root parameters (root length, root volume, root dry weight) were collected at $50 \%$ flowering stage from randomly selected five hills from sample rows using standard procedures. Yield attributes (Panicles $/ \mathrm{m}^{2}$, panicle length, panicle weight, grains/panicle, unfilled grains/panicle, spikelet fertility percentage, 1000-grains weight) were estimated from 10 selected plants in net plot at maturity using standard procedures. For computing grain and biological yield, the net plots were harvested and the produce was sun-dried for constant weight and then total biomass yield was recorded. After threshing, cleaning and drying; the grain, straw and biological yield were determined on $\mathrm{t} \mathrm{ha}^{-1}$ basis. The grain yield was recorded at $14 \%$ moisture content.

Hulling, milling head-rice recovery: From each plot, $200 \mathrm{~g}$ sundried paddy (whole grains) samples were drawn and hulled in a mini rice mill and the weight of brown rice was recorded. Hulling percentage was computed by dividing the weights of brown rice by 
weight of rough rice multiplied by 100 . Hulled brown rice was passed through rice whitening machine for 2 minutes to get milled rice. Milling percentage was worked out by dividing the milled rice by brown rice multiplied by 100 . For estimating head rice recovery, the milled produce was sieved using appropriate sieves to separate whole kernels from the broken ones. Small proportion of whole kernels which passed along with broken ones was hand-separated. Head rice recovery (\%) was calculated by dividing the weight of whole milled rice by weight of rough rice multiplied by 100 .

Protein content and protein yield: Crude protein content in rice grains was obtained by multiplying $\mathrm{N}$ concentration with a Jones factor 5.95 (Jones, 1941). This factor is based on the nitrogen content $(16.8 \%)$ of the major rice protein, glutelin (Jones, 1941). Protein yield in rice grains was worked out using standard methods (Rana etal., 2014).

Water productivity: Total rainfall received during the crop season was $1646.3 \mathrm{~mm}$ (Fig. 1), while no irrigation was applied to the crop. Thus, effective rainfall worked-out to be $1317 \mathrm{~mm}$ using standard procedures (Rana et al., 2014), was the total water-use $(1317 \mathrm{~mm})$. Total water-use efficiency $\left(\mathrm{kg} \mathrm{ha}^{-1} \mathrm{~mm}^{-1}\right)$ and economic water productivity (INR ha ${ }^{-1} \mathrm{~mm}^{-1}$ ) were computed using standard methodology (Adeboye et al., 2015). Market price of rice grains was INR $1500 \mathrm{q}^{-1}$.

Energy dynamics: For assessing energy dynamics and energyuse efficiency of rice crop, each input used in rice production and the respective output, were converted into the form of energy using energy equivalents (Table 2). The energy efficiencies were estimated using standard methods (ISA, 2016).

Soil microbiological analysis: Dehydrogenase enzyme activity of soil samples of experimental plots was estimated by the method of Casida et al. (1964). Soil microbial biomass carbon (SMBC) in soil samples was estimated following the method of Vance et al. (1987). Alkaline phosphatase activity in soil was assayed by the method developed by Tabatabai and Bremner (1969).
Statistical analyse: Data related to each parameter were analyzed as per the procedure of analysis of variance (ANOVA) and significance of split-plot design tested by F-test (Gomez and Gomez, 2010). Standard error of means (SEm \pm ) and least significant difference (LSD) at $5 \%$ level of significance were worked out for each parameter.

\section{Results and Discussion}

The perusal of data revealed that root parameters like root volume and root dry weight were found highest under INM practice followed by inorganic, organic practice and control, respectively (Fig. 2). However, root length was recorded highest in inorganic practice followed by INM and organic practice. Here, better nutrient supply under inorganic and INM treatments led to greater root volume and root dry weight (Suri and Choudhary, 2013; Omran et al., 2020). Rice varieties showed a non-significant effect on root length. Amongst varieties, significantly highest root volume and root dry weight were found in Shahsarang-1 (45.3 cc; $13.69 \mathrm{~g}$ ) both over Lumpnah and Megha SA2 which may be attributed to its genetic characteristics (Verma etal., 2017).

Plant population in each plot was kept same i.e. 2,50,000 plants ha- 1 so as to evaluate the experimental outcome in current study. The number of panicles $\mathrm{m}^{-2}$ and panicle length were found to be highest in INM practice (Table 3), however, panicle weigh was found similar both under organic and INM practices. Number of grains per panicle was highest for INM practice whereas inorganic and organic practices remaining at par with each other showed intermediate magnitude. Number of unfilled grains per panicle was found highest for control and lowest for INM practice. Spikelet fertility was again highest under INM practice (91.4\%). Test weight followed the trend of INM>organic>inorganic>control treatment. INM practice exhibited significantly higher grain $(4.18 \mathrm{t}$ ha $\left.^{-1}\right)$, straw $\left(6.38\right.$ t ha $\left.^{-1}\right)$ and biological yield $\left(10.54\right.$ t ha $\left.^{-1}\right)$ followed by inorganic, organic and control treatment, respectively (Table 4). Grain yield enhancement under INM practice was found to the tune of $56.5 \%$ over control. Harvest index followed the trend of

Table 1: Initial physical and chemical properties of experimental soil

\begin{tabular}{|c|c|c|}
\hline Parameters & Content & Methods used \\
\hline \multicolumn{3}{|l|}{ Physical characteristics } \\
\hline Soil texture & Sandy-clay loam & (Hydrometer method; Bouyoucos, 1962) \\
\hline Soil bulk density $\left(0-15 \mathrm{~cm}\right.$ layer) $\left(\mathrm{g} \mathrm{cm}^{-3}\right)$ & 1.05 & (Rana et al., 2014) \\
\hline \multicolumn{3}{|l|}{ Chemical characteristics } \\
\hline Soil organic carbon $(\%)$ & 2.45 & (Walkley and Black, 1934) \\
\hline Alkaline permanganate oxidizable $\mathrm{N}$ & 236.0 & (Subbiah and Asija, 1956) \\
\hline Available phosphorus $\left(\mathrm{P}_{2} \mathrm{O}_{5} \mathrm{~kg} \mathrm{ha}^{-1}\right)$ & 6.3 & (Olsen's method; Olsen et al., 1954) \\
\hline Available potassium $\left(\mathrm{K}_{2} \mathrm{O} \mathrm{kg} \mathrm{ha}{ }^{-1}\right)$ & 293.4 & (Flame photometer method; Hanway and Heidel, 1952) \\
\hline $\mathrm{pH}(1: 2.5$ soil: water $)$ & 4.8 & (Elico pH meter; Piper, 1950) \\
\hline \multicolumn{3}{|l|}{ Biological characteristics } \\
\hline MBC ( $\mu$ g microbial biomass carbon $\mathrm{g}^{-1}$ soil) & 142.4 & (Vance et al., 1987) \\
\hline Dehydrogenase activity ( $\mu \mathrm{g}$ TPF $\mathrm{g}^{-1}$ soil day ${ }^{-1}$ ) & 11.4 & (Casida et al., 1964) \\
\hline Alkaline phosphatase ( $\mu \mathrm{g}$ PNP $\mathrm{g}^{-1}$ soil $\left.\mathrm{hr}^{-1}\right)$ & 20.2 & (Tabatabai and Bremner, 1969) \\
\hline
\end{tabular}


Table 2: Energy equivalent used for input and output of rice production (Source: Rana et al., 2014; ISA, 2016)

\begin{tabular}{ll}
\hline A. Inputs & Energy equivalents \\
1. Human labour & $1.95 \mathrm{MJ} \mathrm{man} \mathrm{hr}^{-1}$ \\
2. Machinery & $158.3 \mathrm{MJ} \mathrm{hr}^{-1}$ \\
3. Diesel fuel & $56.31 \mathrm{MJ} \mathrm{I}^{-1}$ \\
4. Chemical fertilizers/organic manures/biofertilizers: & \\
$\quad$ Nitrogen $(\mathrm{N})$ & $60.6 \mathrm{MJ} \mathrm{kg}^{-1}$ \\
Phosphorus $\left(\mathrm{P}_{2} \mathrm{O}_{5}\right)$ & $11.1 \mathrm{MJ} \mathrm{kg}^{-1}$ \\
$\quad$ Potassium $\left(\mathrm{K}_{2} \mathrm{O}\right)$ & $6.7 \mathrm{MJ} \mathrm{kg}^{-1}$ \\
$\quad$ Farmyard manure $(\mathrm{FYM})$ & $0.3 \mathrm{MJ} \mathrm{kg}^{-1}$ \\
5. Chemicals: & \\
$\quad$ Herbicides & $238.0 \mathrm{MJ} \mathrm{kg}^{-1}$ \\
$\quad$ Fungicides/Pesticides & $1.95 \mathrm{MJ} \mathrm{kg}^{-1}$ \\
6. Water for irrigation & $1.02 \mathrm{MJ} \mathrm{m}^{-3}$ \\
7. Seed (rice) & $14.57 \mathrm{MJ} \mathrm{kg}^{-1}$ \\
B. Outputs & \\
1. Main product & $14.57 \mathrm{MJ} \mathrm{kg}^{-1}$ \\
2. By-product & $12.5 \mathrm{MJ} \mathrm{kg}^{-1}$ \\
\hline
\end{tabular}

Table 3: Effect of nutrient management practices and rice varieties on yield attributes of rice

\begin{tabular}{llllllll}
\hline Treatments & $\begin{array}{l}\text { Panicles } \\
\left(\mathbf{m}^{-2}\right)\end{array}$ & $\begin{array}{l}\text { Panicle } \\
\text { length }(\mathbf{c m})\end{array}$ & $\begin{array}{l}\text { Panicle } \\
\text { weight }(\mathbf{g})\end{array}$ & $\begin{array}{l}\text { Grains } \\
\text { panicle }\end{array}$ & $\begin{array}{l}\text { Unfilled grains } \\
\text { panicle }{ }^{-1}\end{array}$ & $\begin{array}{l}\text { Spikelet } \\
\text { fertility }(\%)\end{array}$ & $\begin{array}{l}\text { 1000-grain } \\
\text { weight }(\mathbf{g})\end{array}$ \\
\hline $\begin{array}{l}\text { Nutrient management practices } \\
\text { Organic }\end{array}$ & & & & & & & \\
INM & 191.3 & 25.2 & 4.1 & 139.0 & 15.0 & 90.2 & 26.05 \\
Inorganic & 199.5 & 26.8 & 4.1 & 146.9 & 13.8 & 91.4 & 26.25 \\
Control & 193.9 & 26.2 & 4.0 & 141.2 & 17.7 & 88.9 & 26.04 \\
CD $(P=0.05)$ & 135.9 & 18.9 & 3.1 & 106.9 & 27.8 & 79.3 & 25.77 \\
Rice varieties & 1.5 & 0.8 & 0.03 & 3.6 & 1.2 & 0.6 & 0.27 \\
Shahsarang-1 & 185.7 & 24.3 & 3.8 & 138.7 & 16.8 & 88.9 & 23.68 \\
Lumpnah & 180.2 & 23.8 & 3.7 & 131.6 & 18.4 & 87.3 & 25.21 \\
Megha SA2 & 174.5 & 24.8 & 3.9 & 130.1 & 20.5 & 86.1 & 29.20 \\
SEm \pm & 0.9 & 0.4 & 0.01 & 0.81 & 0.23 & 0.17 & 0.06 \\
CD $(P=0.05)$ & 2.7 & NS & 0.04 & 2.4 & 0.7 & 0.5 & 0.17 \\
\hline
\end{tabular}

Table 4: Effect of nutrient management practices and rice varieties on crop productivity and harvest index of rice

\begin{tabular}{lllll}
\hline Treatments & $\begin{array}{l}\text { Grain yield } \\
\left(\mathrm{t} \mathrm{ha}^{-1}\right)\end{array}$ & $\begin{array}{l}\text { Straw yield } \\
\left(\mathrm{t} \mathrm{ha}^{-1}\right)\end{array}$ & $\begin{array}{l}\text { Biological yield } \\
\left(\mathrm{t} \mathrm{ha}^{-1}\right)\end{array}$ & $\begin{array}{l}\text { Harvest } \\
\text { index }(\%)\end{array}$ \\
\hline $\begin{array}{l}\text { Nutrient management practices } \\
\text { Organic }\end{array}$ & & & & 38.15 \\
INM & 3.74 & 6.05 & 9.79 & 39.58 \\
Inorganic & 4.18 & 6.36 & 10.54 & 38.93 \\
Control & 4.02 & 6.29 & 10.31 & 36.52 \\
SEm \pm & 2.26 & 3.90 & 6.16 & 0.53 \\
CD $(P=0.05)$ & 0.06 & 0.05 & 0.07 & 1.83 \\
Rice varieties & 0.21 & 0.18 & 0.24 & 39.98 \\
Shahsarang-1 & & & & 38.63 \\
Lumpnah & 3.86 & 5.73 & 9.59 & 36.27 \\
Megha SA2 & 3.60 & 5.66 & 9.26 & 0.35 \\
SEm \pm & 3.19 & 5.56 & 8.75 & 1.03 \\
CD $(P=0.05)$ & 0.05 & 0.02 & 0.06 & 0.18 \\
\hline
\end{tabular}


Table 5: Effect of nutrient management practices and rice varieties on protein content, protein yield, hulling, milling and head-rice recovery of rice

\begin{tabular}{llllll}
\hline Treatments & $\begin{array}{l}\text { Protein content } \\
(\%)\end{array}$ & $\begin{array}{l}\text { Protein yield } \\
\left.(\mathbf{k g ~ h a})^{-1}\right)\end{array}$ & $\begin{array}{l}\text { Hulling } \\
(\%)\end{array}$ & $\begin{array}{l}\text { Milling } \\
(\%)\end{array}$ & $\begin{array}{l}\text { Head-rice } \\
\text { recovery }(\%)\end{array}$ \\
\hline $\begin{array}{l}\text { Nutrient management practices } \\
\text { Organic }\end{array}$ & & & & 51.02 \\
INM & 7.38 & 276.9 & 67.83 & 58.34 & 53.55 \\
Inorganic & 7.86 & 329.0 & 68.58 & 59.96 & 52.62 \\
Control & 7.59 & 305.8 & 68.01 & 59.04 & 48.67 \\
SEm \pm & 6.85 & 154.7 & 64.38 & 56.23 & 0.18 \\
CD $(P=0.05)$ & 0.14 & 7.95 & 0.136 & 0.14 & 0.63 \\
Rice varieties & 0.49 & 27.5 & 0.47 & 0.50 & 52.15 \\
Shahsarang-1 & & & & & 52.27 \\
Lumpnah & 7.62 & 297.4 & 67.85 & 58.88 & 49.99 \\
Megha SA2 & 7.46 & 271.2 & 67.32 & 58.54 & 0.14 \\
SEm \pm & 7.18 & 231.1 & 66.43 & 57.77 & 0.43 \\
CD $(P=0.05)$ & 0.13 & 6.44 & 0.22 & 0.15 & 0.45 \\
\hline
\end{tabular}

Table 6: Effect of nutrient management practices and rice varieties on cost of cultivation, gross and net returns, and B: C ratio of rice

\begin{tabular}{lllll}
\hline Treatments & $\begin{array}{l}\text { Cost of cultivation } \\
\left(\text { INR ha }{ }^{-1}\right)\end{array}$ & $\begin{array}{l}\text { Gross returns } \\
\left(\text { INR ha }{ }^{-1}\right)\end{array}$ & $\begin{array}{l}\text { Net returns } \\
\left(\text { INR ha } \mathbf{~}^{-1}\right.\end{array}$ & B: C ratio \\
\hline $\begin{array}{l}\text { Nutrient management practices } \\
\text { Organic }\end{array}$ & 34,680 & & & \\
INM & 29,205 & 68,210 & 33,530 & 1.97 \\
Inorganic & 21,741 & 75,382 & 46,177 & 2.58 \\
Control & 17,269 & 72,882 & 51,141 & 3.35 \\
SEm \pm & - & 41,657 & 24,388 & 2.41 \\
CD $(P=0.05)$ & - & 904 & 904 & 0.04 \\
Rice varieties & & 3,128 & 3,128 & 0.14 \\
Shahsarang-1 & 25,724 & & & 2.77 \\
Lumpnah & 25,724 & 69,315 & 43,591 & 2.60 \\
Megha SA2 & 25,724 & 65,371 & 39,647 & 2.36 \\
SEm \pm & - & 58,913 & 33,189 & 0.04 \\
CD $(P=0.05)$ & - & 758 & 758 & 0.11 \\
\hline
\end{tabular}

Table 7: Effect of nutrient management practices and rice varieties on energy dynamics of rice crop

\begin{tabular}{lllllll}
\hline Treatments & $\begin{array}{l}\text { Energy input } \\
\left(\mathbf{M J ~ h a}^{-1}\right)\end{array}$ & $\begin{array}{l}\text { Energy output } \\
\left(\mathbf{M J ~ h a}^{-1}\right)\end{array}$ & $\begin{array}{l}\text { Energy-use } \\
\text { efficiency }\end{array}$ & $\begin{array}{l}\text { Net energy } \\
\left(\mathbf{M J ~ h a}^{-1}\right)\end{array}$ & $\begin{array}{l}\text { Specific energy } \\
\left(\mathbf{M J ~ k g}^{-1}\right)\end{array}$ & $\begin{array}{l}\text { Energy productivity } \\
\left(\mathbf{k g ~ M J ~}^{-1}\right)\end{array}$ \\
\hline $\begin{array}{l}\text { Nutrient management practices } \\
\text { Organic }\end{array}$ & 10071 & 130091 & 12.92 & 120021 & 1.031 & 0.972 \\
INM & 9529 & 140342 & 14.73 & 130813 & 0.906 & 1.106 \\
Inorganic & 8948 & 137210 & 15.33 & 12863 & 0.868 & 1.152 \\
Control & 3119 & 81707 & 26.20 & 78588 & 0.508 & 1.976 \\
SEm \pm & - & 950 & 0.29 & 949 & 0.005 & 0.022 \\
CD $(P=0.05)$ & - & 3286 & 1.01 & 3286 & 0.020 & 0.075 \\
Rice varieties & & & & & & 1.361 \\
Shahsarang-1 & 7917 & 127819 & 18.13 & 119902 & 0.794 & 1.307 \\
Lumpnah & 7917 & 123243 & 17.37 & 115326 & 0.822 & 0.236 \\
Megha SA2 & 7917 & 115954 & 16.38 & 108035 & 0.869 & 0.015 \\
SEm \pm & - & 862 & 0.20 & 862 & 0.005 & 0.044 \\
CD $(P=0.05)$ & - & 2583 & 0.61 & 2583 & 0.016 & \\
\hline
\end{tabular}


Table 8: Effect of nutrient management practices and rice varieties on soil microbiological properties of soil after the harvest of rice crop

\begin{tabular}{|c|c|c|c|}
\hline Treatments & $\begin{array}{l}\text { Soil microbial } \\
\text { biomass carbon } \\
\text { ( } \mu \mathrm{g} \mathrm{g}^{-1} \text { soil) }\end{array}$ & $\begin{array}{l}\text { Alkaline phosphatase } \\
\text { enzyme activity } \\
\left(\mu \mathrm{g} \mathrm{p}-\mathrm{NP} \mathrm{g}^{-1} \text { soil } 24 \mathrm{hr}^{-1} \text { ) }\right.\end{array}$ & $\begin{array}{l}\text { Dehydrogenase } \\
\text { enzyme activity } \\
\left(\mu \mathrm{g} \text { TPF } \mathrm{g}^{-1} \text { soil } \mathrm{hr}^{-1}\right)\end{array}$ \\
\hline \multicolumn{4}{|c|}{ Nutrient management practices } \\
\hline Organic & 140.9 & 223.7 & 10.92 \\
\hline INM & 161.7 & 224.5 & 11.92 \\
\hline Inorganic & 154.6 & 220.1 & 10.66 \\
\hline Control & 129.6 & 214.3 & 8.25 \\
\hline SEm \pm & 3.5 & 2.1 & 0.37 \\
\hline $\mathrm{CD}(P=0.05)$ & 11.9 & 7.2 & 1.30 \\
\hline \multicolumn{4}{|l|}{ Rice varieties } \\
\hline Shahsarang-1 & 147.3 & 222.1 & 11.02 \\
\hline Lumpnah & 142.5 & 220.2 & 10.05 \\
\hline Megha SA2 & 150.2 & 219.7 & 10.23 \\
\hline $\mathrm{SEm} \pm$ & 1.9 & 1.3 & 0.46 \\
\hline $\mathrm{CD}(P=0.05)$ & 5.6 & NS & NS \\
\hline
\end{tabular}

INM> inorganic>organic>control treatment. Higher magnitude of shoot and root growth parameters under INM practice may be attributed to good early vigorous plant growth under INM practice with better leaf area index and photosynthesis which resulted in superior yield attributes and rice yield (Varatharajan et al., 2019a, 2019b; Omran et al., 2020). Further, better performance of rice varieties under INM practice may probably be accrued to good crop establishment and better anchorage of roots (Dass et al.,
2016). That's' why the highest grain, straw and biological yield were observed in INM practice. Among varieties, Shahsarang-1 recorded maximum panicles $\mathrm{m}^{-2}$, grains panicle ${ }^{-1}$ and spikelet fertility followed by Lumpnah and Megha SA2 (Table 3). Both panicle length and panicle weight were highest in Megha SA2, followed by Shahsarang-1 and Lumpnah, respectively. Highest test weight and number of unfilled grains per panicle were found in Megha SA2 followed by Lumpnah and Shahsarang-1. Overall,

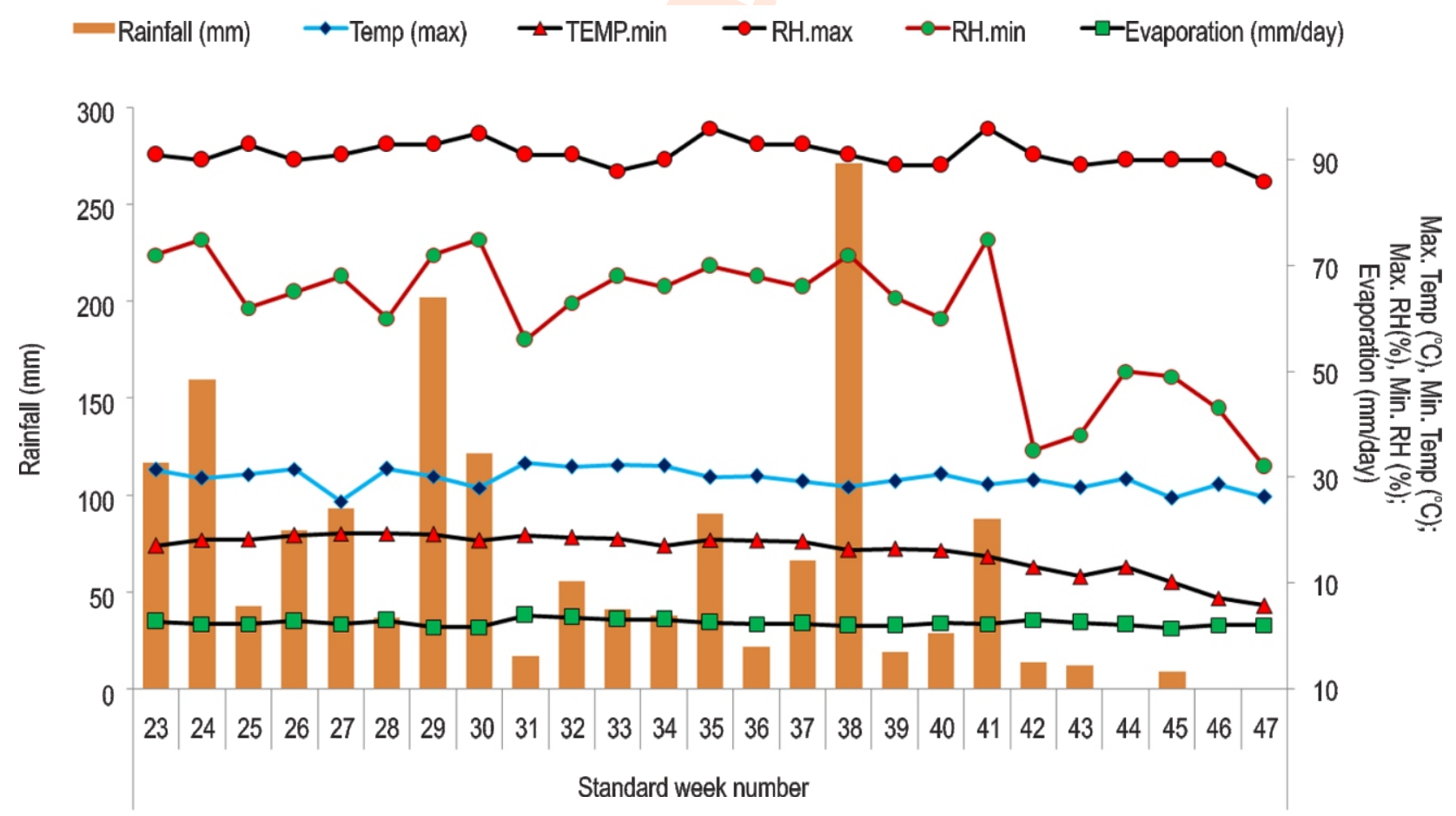

Fig. 1: Mean weekly meteorological parameters during the crop growth period (Kharif 2016). 

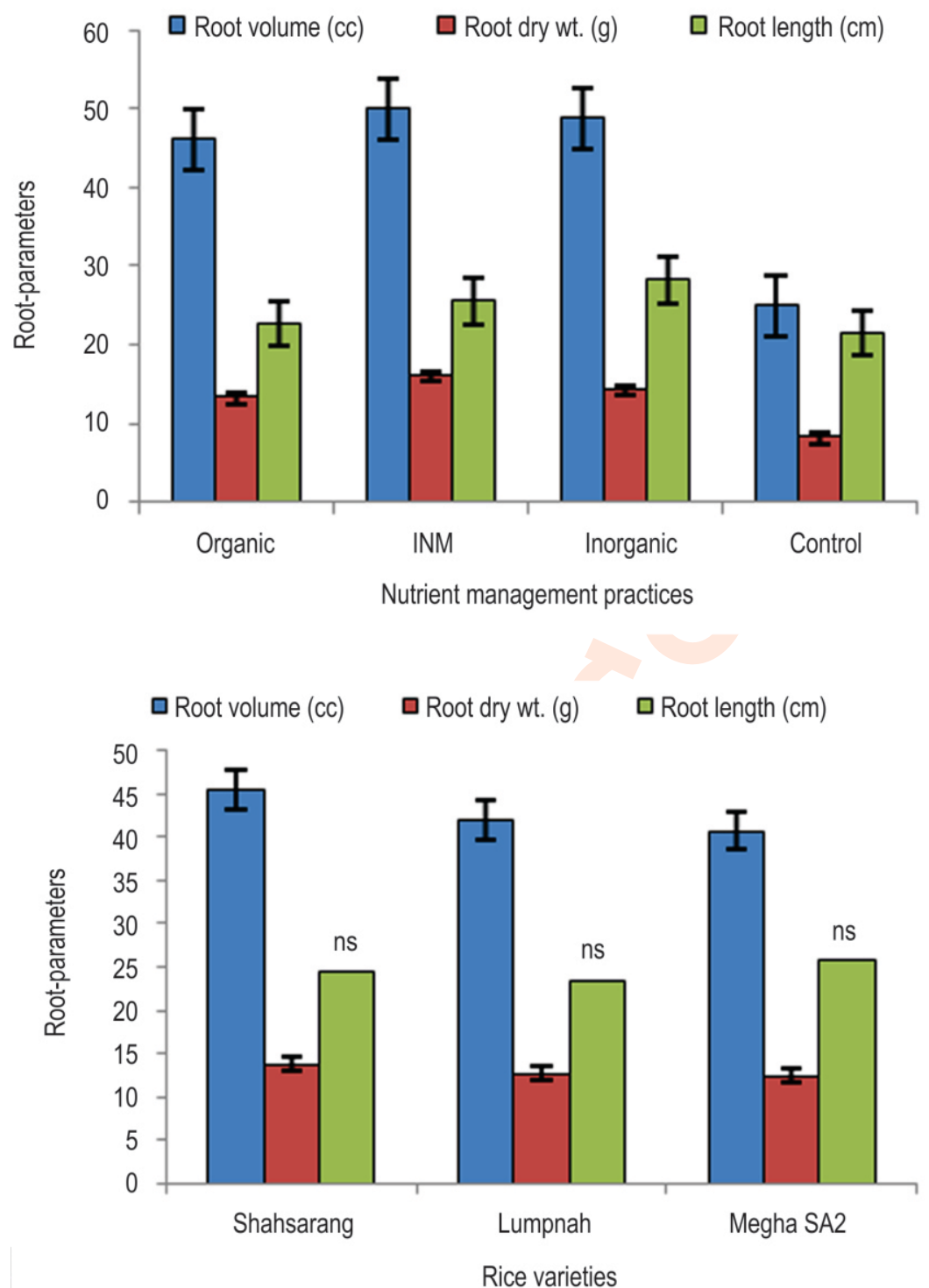

Fig. 2: Effect of nutrient management practices and rice varieties on root parameters of rice at maximum flowering stage.

Shahsarang-1 exhibited significantly higher grain $\left(3.86\right.$ tha $\left.^{-1}\right)$, straw $\left(5.73 \mathrm{t} \mathrm{ha}^{-1}\right)$ and biological yield $\left(9.59 \mathrm{tha}^{-1}\right)$ followed by Lampnah and Megha SA2 (Table 4). Harvest index followed the trend of Shahsarang-1>Lampnah>Megha SA2. Since, these varieties had differential production potential (Diwakar, 2012), which might have led to differential response to applied nutrients/nutrient management practice leading to variation in yield attributes, yield and harvest index (Choudhary and Suri, 2014).

INM practice exhibited highest hulling, milling, head-rice recovery, protein content and protein yield followed by inorganic and organic practices, respectively all of which were statistically superior over control (Table 5). Among varieties, hulling, milling and protein yield were highest in Shahsarang-1 followed by
Lumpnah and Megha SA2. But, head-rice recovery was highest in Lumpnah followed by Shahsarang-1 and Megha SA2. Significantly higher protein content and protein yield were observed in INM practice with least values in control. This may be attributed to improved soil physico-chemical and microbiological properties, nutrient availability and soil rhizospheric conditions which collectively helped in harnessing higher rice productivity with better quality (Choudhary and Suri, 2009; Paul et al., 2016; Singh et al., 2020a). Among varieties, hulling and milling were highest under Shahsarang-1 followed by Lumpnah and Megha SA2; whereas, highest head-rice recovery was observed under Lumpnah followed by Shahsarang-1 and Megha SA2, respectively which may be accrued to the specific varietal characteristics (Pooniya et al., 2019). The results indicated that 

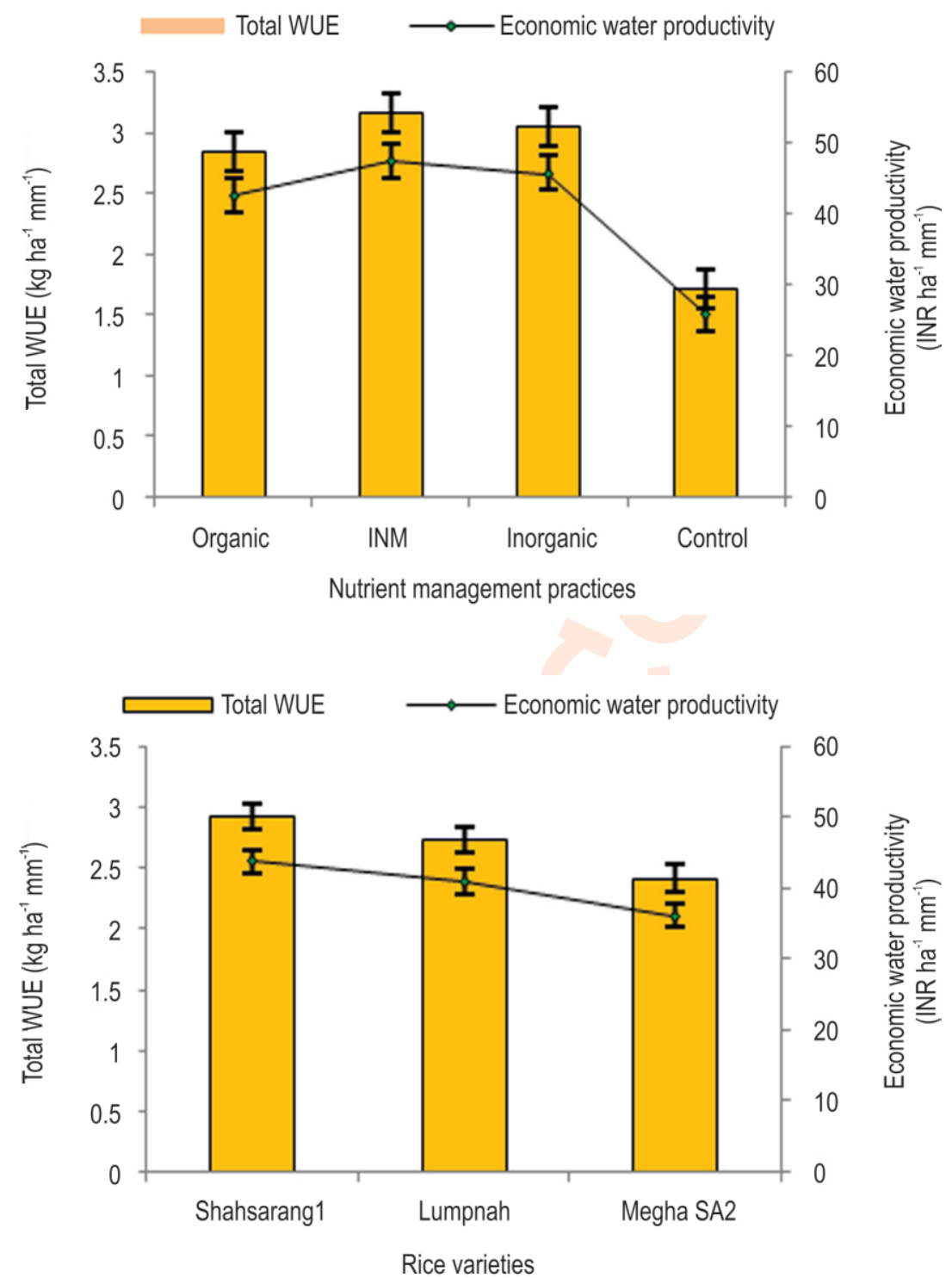

Fig. 3: Effect of nutrient management practices and rice varieties on total water use efficiency and economic water productivity of rice.

INM practice exhibited highest total water-use efficiency (TWUE) $\left(3.17 \mathrm{~kg} \mathrm{ha}^{-1} \mathrm{~mm}^{-1}\right)$ and economic water productivity (EWP) (47.6 INR ha ${ }^{-1} \mathrm{~mm}^{-1}$ ) followed by inorganic, organic practice and control, respectively (Fig. 3). In general, TWUE and EWP followed the similar trend as that of rice grain yield with significantly higher values under INM practice. Among varieties, TWUE and EWP again followed the similar trend as that of their grain yield i.e. Shahsarang-1>Lampnah>Megha Sa2.

As, total water-use (TWU) was constant (1317 mm) under different nutrient management practices. Hence, higher crop productivity under INM practice again enhanced the water productivity in current study (Dass et al., 2016). It indicates that integration of $50 \%$ RDF alongwith FYM in rice may prove as best fertilization schedule to realize highest rice productivity and WUE in eastern Himalayas. Cost of cultivation (INR ha ${ }^{-1}$ ) ranged between INR 17,269-34,680 ha $^{-1}$ under different nutrient management practices due to varying inputs and crop management practices (Table 6). Significantly higher gross returns were observed in INM practice (INR 75,382 ha ${ }^{-1}$ ) which was followed by inorganic, organic practice and control treatment (Table 6). However, higher net returns (INR 51,141 ha ${ }^{-1}$ ) and B: C ratio (3.35) were observed in inorganic practice which was followed by INM, organic practice and control, respectively. Since, gross returns are the sum of the product of respective grain and straw yields under different treatments and their respective 
prices (Rana et al., 2014). Thus, gross returns followed the similar trend as that of grain and straw yield. Under inorganic practice, higher net returns and $\mathrm{B}$ : $\mathrm{C}$ ratio may be accrued to comparatively higher grain and straw yield but with lower cost of cultivation compared to INM and organic practices (Choudhary et al., 2007). Among varieties, Shahsarang-1 gave significantly higher gross and net returns and $\mathrm{B}$ : $\mathrm{C}$ ratio followed by Lampnah and Megha SA2; following the similar trend as that of grain and straw yield. Hence, current economics trend can be attributed to varietal make-up and differential production potential (Diwakar, 2012).

The energy input ranged between 3,119-10,071 $\mathrm{MJ} \mathrm{ha}^{-1}$ among different nutrient management practices and followed the trend of organic $>\mid \mathrm{NM}>$ inorganic $>$ control treatment (Table 7). INM practice had highest energy output $\left(1,40,342 \mathrm{MJ} \mathrm{ha}^{-1}\right)$ as well as highest net energy $\left(1,30,813 \mathrm{MJ}^{-1} \mathrm{a}^{-1}\right)$, followed by inorganic and organic practices, respectively. The control treatment had highest energy-use efficiency (15.33) and energy productivity $(1.976 \mathrm{~kg}$ $\mathrm{MJ}^{-1}$ ) followed by inorganic, INM and organic practice. Organic practice had highest specific energy (1.031 $\left.\mathrm{MJ}_{\text {ha }}{ }^{-1}\right)$ followed by INM and inorganic practice. Variation in energy input among nutrient management practices may be attributed to varying inputs and crop management practices like tillage, fertilizer application, water, weet, pest and disease management, etc. Likewise, higher energy consumption under organic practice was due to higher energy equivalents of FYM applied (Varatharajan et al., 2019a). On the other hand, higher energy output and net energy under INM over the organic practice may be attributed to higher respective grain and straw yield. Organic practice exhibited highest specific energy due to better energy input/product output ratio (Varatharajan et al., 2019a). TWUE and EWP again followed the similar trend as that of their grain yield i.e. Shahsarang-1>Lampnah>Megha SA2. which may be accrued to the specific varietal characteristics (Diwakar, 2012).

Soil microbial biomass carbon (SMBC) was significantly higher under INM practice (161.7 $\mu \mathrm{g} \mathrm{g}^{1}$ soil) followed by organic and inorganic practice and control, respectively. Among rice varieties, highest SMBC was reported for Megha SA2 (150.2 $\mu \mathrm{g}$ $\mathrm{g}^{1}$ soil) followed by Shahsarang-1 and Lumpnah (Table 8). Dehydrogenase activity (DHA) was significantly higher under INM practice (11.92 $\mu \mathrm{g}$ TPF $\mathrm{g}^{-1}$ soil $\mathrm{hr}^{-1}$ ) followed by inorganic, organic practice and control. Alkaline phosphatase activity (APA) was significantly higher under INM practice followed by organic, inorganic practice and control, respectively. Among varieties, highest DHA was reported for Shahsarang-1 followed by Megha SA2 and Lumpnah while highest APA was reported for Shahsarang-1 followed by Lumpnah and Megha SA2 (Table 8). Paul et al. (2014) reported that FYM alongwith inorganic NPK greatly improves the crop productivity and bio-fertility of soil with substantial influence on SMBC, DHA and APA enzyme activity. Hence, higher organic matter additions under INM and organic nutrient management practices might have acted as appropriate triggering force for improved soil biological activities (Choudhary and Rahi, 2018; Yadav et al., 2019; Singh et al., 2020b). Overall, it is concluded that INM practice and rice variety 'Shahsarang-1' can be recommended for enhancing the rice productivity, profitability, grain quality, resource-use efficiency and soil biology in eastern Himalayan region of India.

\section{Acknowledgments}

Authors are thankful to ICAR-Indian Agricultural Research Institute, New Delhi; ICAR-Indian Agricultural Research Institute, Assam; and Indian Council of Agricultural Research (ICAR), New Delhi for providing the technical and financial support. The technical support provided by the Director and Scientists of ICAR-Research Complex for North-Eastern Hill Region, Barapani, Meghalaya, India is also highly acknowledged.

\section{Add-on Information}

Authors' contribution: M.N. Harish, A.K. Choudhary, Y.V. Singh: Experiment execution and writing; V. Pooniya, A. Das, S. Babu: Experiment execution; A. Dass, T. Varatharajan: Lab analysis and writing.

Research content: The research content is original and has not been published elsewhere

\section{Ethical approval: NotApplicable}

Conflict of interest: The authors declare that there is no conflict of interest.

\section{Data from other sources: NotApplicable}

Consent to publish: All authors agree to publish the paper in Journal of Environmental Biology.

\section{References}

Adeboye, O., B.S Chultz, K.O. Adekalu and K. Prasad: Crop water productivity and economic evaluation of drip-irrigated soybeans. Agri. Food Sec., 4, 1186-1206(2015).

Bouyoucos, G.J.: Hydrometer method improved for making particle size analysis of soils. Agron. J., 54, 464-465(1962).

Casida, L.E., D.A. Klein and T. Santoro: Soil dehydrogenase activity. Soil Sci., 93, 371-376 (1964).

Choudhary, A.K. and S. Rahi: Organic cultivation of high yielding turmeric (Curcuma longa L.) cultivars - A viable alternative to enhance rhizome productivity, profitability, quality and resource-use efficiency in monkey-menace areas of north-western Himalayas. Indust. Crops Prod., 124, 495-504 (2018).

Choudhary, A.K. and V.K. Suri: Effect of organic manures and inorganic fertilizers on productivity, nutrient uptake and soil fertility in wheat (Triticum aestivum)-paddy (Oryza sativa) crop sequence in western Himalayas. Curr. Adv. Agric. Sci., 1, 65-69 (2009).

Choudhary, A.K. and V.K. Suri: Integrated nutrient management technology for direct-seeded upland rice (Oryza sativa) in northwestern Himalayas. Commun. Soil Sci. PI. Anal., 45, 777-784 (2014).

Choudhary, A.K. and V.K. Suri: System of rice intensification in promising rice hybrids in NW Himalayas: Crop and water productivity, quality and economic profitability. J. Plant Nutr., 41, 1020-1034 (2018a). 
Choudhary, A.K. and V.K. Suri: System of rice intensification in short duration rice hybrids under varying bio-physical regimes: New opportunities to enhance rice productivity and rural livelihoods in north-western Himalayas under a participatory-mode technology transfer program. J. Plant Nutr., 41, 2581-2605 (2018b).

Choudhary, A.K., R.C. Thakur and N. Kumar: Effect of organic manures and chemical fertilizers on productivity and profitability in wheatrice crop sequence. Oryza, 44, 239-242 (2007).

Dass, A., S. Chandra, A.K. Choudhary, G. Singh and S. Sudhishri: Influence of field re-ponding pattern and plant spacing on rice root-shoot characteristics, yield, and water productivity of two modern cultivars under SRI management in Indian Mollisols. Paddy WaterEnv., 14, 45-59 (2016).

Diwakar, M.C.: Rice varieties released or notified during 1996-2005. Directorate of Rice Dev. Patna, p. 18 (2012).

Gomez, K.A. and A.A. Gomez: Statistical procedures for agricultural research, $2^{\text {nd }}$ Edn., John Wiley and Sons, New York, p.704 (2010).

Hanway, J.J. and H. Heidel: Soil analysis methods as used in lowa State College Soil Testing Laboratory, Bulletin 57. lowa State College of Agriculture, USA, p. 131 (1952).

Harish, M.N., A.K. Choudhary, Y.V. Singh, V. Pooniya, A. Das, T. Varatharajan and S. Babu: Influence of varieties and nutrient management practices on productivity, nutrient acquisition and resource-use efficiency of rice in north-eastern hill region of India. Indian J. Agric. Sci., 89, 367-370 (2019).

ISA: Agronomy Terminology, $6^{\text {th }}$ Edn., Indian Society of Agronomy, New Delhi, India (2016).

Jones, D.B.: Factors for converting percentages of nitrogen in foods and feeds into percentages of protein. USDA Circular No. 183, Washington, DC, USA (1941).

Kumar, A., A.K. Choudhary and V.K. Suri: Influence of AM fungi, inorganic phosphorus and irrigation regimes on plant water relations and soil physical properties in okra-pea cropping system in Himalayan acid Alfisol. J. Plant Nutr., 39, 666-682 (2016).

Olsen, S.R., C.V. Cole, F.S. Watanable and L.A. Dean: Estimation of available phosphorus in soils by extraction with sodium bicarbonate. USDA Circular No. 939 (1954).

Omran, H.A., A. Dass, G.A. Rajanna, S. Dhar, A.K. Choudhary, S.L. Meena and S.S. Rathore: Root-shoot characteristics, yield and economics of mungbean (Vigna radiata L.) under variable rates of phosphorus and nitrogen. Bangladesh J. Bot., 49, 13-19 (2020).

Paul, J., A.K. Choudhary, S. Sharma, Savita, M. Bohra, A.K. Dixit and P. Kumar: Potato production through bio-resources: Long-term effects on tuber productivity, quality, carbon sequestration and soil health in temperate Himalayas. Scientia Hort., 213, 152-163 (2016).

Paul, J., A.K. Choudhary, V.K. Suri, A.K. Sharma, V. Kumar and Shobhna: Bioresource nutrient recycling and its relationship with biofertility indicators of soil health and nutrient dynamics in rice-wheat cropping system. Commun. Soil Sci. Plant Anal., 45, 912-924 (2014).

Piper, C.S.: Soil and Plant Analysis (Indian Ed.). Hane Pub., Bombay, India (1950).
Pooniya, V., A.K. Choudhary, R.S. Bana and Pankaj: Zinc bio-fortification and kernel quality enhancement in elite Basmati rice cultivars of South-Asia through legume residue-recycling and zinc fertilization. Indian J. Agric. Sci., 89, 279-287 (2019).

Rana, K.S., A.K. Choudhary, S. Sepat, R.S. Bana and A. Dass: Methodological and Analytical Agronomy. Post Graduate School, Indian Agricultural Research Institute, New Delhi, India. p. 276 (2014).

Singh, U., A.K. Choudhary and S. Sharma: Agricultural practices modulate the bacterial communities, and nitrogen cycling bacterial guild in rhizosphere: Field experiment with soybean. J. Sci. Food Agric. Published online: https://doi.org/10.1002/jsfa.10893(2020a).

Singh, U., A.K. Choudhary and S. Sharma: Comparative performance of conservation agriculture vis-a-vis organic and conventional farming, in enhancing plant attributes and rhizospheric bacterial diversity in Cajanus cajan: A field study. Eur. J. Soil Biol., 99, 103197 (2020b).

Subbaiah, B.V. and G.L. Asija: A rapid procedure for determination of available-N in soil. Curr. Sci., 25, 259-262 (1956).

Suri, V.K. and A.K. Choudhary: Effects of vesicular arbuscular mycorrhizae and applied phosphorus through targeted yield precision model on root morphology, productivity and nutrient dynamics in soybean in an acid Alfisol. Commun. Soil Sci. Plant Anal., 44, 2587-2604 (2013).

Tabatabai, M.A. and J.M. Bremner: Use of p-nitrophenyl phosphate for assay of soil phosphatase activity. Soil Biol. Biochem., 1, 301-307 (1969).

Vance, E.D.P., C. Brookes and D.S. Jenkinson: An extraction method for measuring soil microbial biomass carbon. Soil Biol. Biochem., 19, 703-704 (1987).

Varatharajan, T., A.K. Choudhary, V. Pooniya, A. Dass, D.S. Rana, K.S. Rana and M.N. Harish: Effect of integrated crop management practices on root-shoot characteristics, yield and nutrient harvest index of pigeonpea (Cajanus cajan) under irrigated north Indian plains. Indian J. Agron., 64, 270-274 (2019b).

Varatharajan, T., A.K. Choudhary, V. Pooniya, A. Dass, M.C. Meena, B, Gurung and M.N. Harish: Influence of integrated crop management practices on yield, PAR interception, resource-useefficiency and energetics in pigeonpea in north Indian Plains. J. Environ. Biol., 40, 1204-1210 (2019a).

Verma, P., Y.V. Singh, A.K. Choudhary, M. Ahuja and C. Chaudhary: Root parameters and grain quality of lowland rice as affected by different nutrient management practices and microbial inoculants. J. Pharmacogn. Phytochem., 6, 2392-2394 (2017).

Walkley, A. And I.A. Black: An examination of Degtjareff method for determining soil organic matter and a proposed modification of the chromic acid titration method. Soil Sci., 37, 29-37 (1934).

Yadav, G.S., A. Das, R. Lal, S. Babu, M. Datta, R.S. Meena, S.B. Patil and R. Singh: Impact of no-till and mulching on soil carbon sequestration under rice-rapeseed cropping system in hilly agroecosystem of the Eastern Himalayas, India. Agric. Ecosyst. Environ., 275, 81-92 (2019). 